BOOK REVIEW

\title{
Sam Solecki (Ed.), Yours, Al: The Collected Letters of Al Purdy. Madeira Park, BC: Harbour Publishing, 2004, 560 pp., \$44.95.
}

\author{
Reviewed by Tom Middlebro', Carleton University (Retired)
}

For all those interested in Canadian poets and poetry, the publication of Yours, Al: The Collected Letters of Al Purdy provides a sumptuous feast. Editor Sam Solecki has printed 376 letters, 332 by Al Purdy and the remainder to him, written between October 1947 when the 28-year-old Purdy was still an aspiring poet and April 2000, when at his death Purdy was generally accepted as one of Canada's best leftist poets. Most numerous are the letters exchanged with Earle Birney, a mentor and friend with whom Purdy corresponded from 1947 up until Birney's final illness, but there are also extensive exchanges with Margaret Laurence, George Woodcock and Sam Solecki. A few of Purdy's correspondents were politicians or scholars such as Pierre Elliott Trudeau, Northrop Frye, Sandra Djwa and Milton Wilson, and he had a lively, difficult correspondence with publisher Jack McClelland. The majority, however, of Purdy's other letters were addressed to friends and fellow practitioners: John Glassco, Irving Layton, Margaret Atwood, Milton Acorn, F. R. Scott, Dennis Lee, Roderick Haig-Brown, Susan Musgrave, D. C. Jones, George Bowering, Fraser Sutherland, Patrick Lane, George Johnston.

Al Purdy's letters often contain references to shared occasions and brief descriptions of current activities, together with anecdotes about other writers. The craft of poetry, however, is always the central topic. This can be illustrated by any of the exchanges but perhaps most easily by that with Earle Birney, as Birney was sufficiently older to be seen first as a model, then as a friend with whom he could be perfectly, and occasionally ribaldly, frank. Al Purdy admired Birney's poetry, in particular "David" (which Purdy made into a radio play for CBC with John Drainie reading), "Mappemounde", "Vancouver Lights", "Bushed" and "The Road to Nijmegen", and believed that Birney was a greater poet than E. J. Pratt, who except in his extravaganzas was stiff. With Birney, Purdy had informed discussions on poetic forms, metrics, diction and source influences-even if he 
bridled at Birney's dismissal of his own youthful source model, Bliss Carman. Purdy could describe his own thrill at poetic composition, "some exultation in words", "euphoric written instant", as well as his mystic and barren periods. The two poets shared teaching and public reading experiences, interviews, quarrels, books read and criticized, the problem of Canadian writers gaining acceptance abroad, travel-Purdy was particularly impressed with Mexico, the Soviet Union and Cuba-, mutual acquaintances and their works, and the poems and poetry books each was currently working on. They sometimes exchanged drafts. Throughout the correspondence and always implicit are Purdy's tenacious loyalties to his wife, his friends, his country and his poetic vocation.

Yours, Al: The Collected Letters of Al Purdy provides an invaluable glimpse of the texture of life lived by a Canadian poet in the second half of the twentieth century. Purdy's lively letters enrich but do not alter the impression of his personality gained from reading his poetry. As in the poems, so in the letters, there are areas of silence. We are presented with Purdy ineptly social or morosely solitary, but only conventionally familial. There is one brief letter to Purdy's son and none to his wife Eurithe. Yet she is omnipresent as the feminine reality principle, as in Purdy's poetry evoking the responses appropriate to the mood-induced masks of the masculine fantasist, from perpetually libidinous adolescent, "Song of the Impermanent Husband", to time-haunted seer, "The Horseman of Agawa": humorously resigned acceptance, deep respect.

Editor Sam Solecki is to be congratulated on the making of this volume. 